\title{
Pastoral Care and Politics: Introducing a Special Issue
}

\author{
Ryan LaMothe
}

Published online: 11 September 2013

(C) Springer Science+Business Media New York 2013

One never knows. A couple of years ago, I (Ryan LaMothe) had the pleasure of chatting with Dr. Bruce Rogers-Vaughn about political issues and pastoral care. We both have deep concerns about the current state of affairs in the United States and what it means for the future generations. Together, we mused about inviting various scholars to address the broad topic of the political dimensions of pastoral care and politics. Our hope was/is to expand the conversation and, perhaps, to mobilize further scholarly and civic engagement. Having corresponded with Lewis Rambo over the years, I proposed to him the idea of devoting an issue of Pastoral Psychology to pastoral care and politics. Because of Lewis's own passion about politics, he enthusiastically agreed to do this. When we invited authors, we decided to keep the topic sufficiently vague so that people would be creative in their choice of subjects. I think we succeeded. One never knows what will emerge in a conversation.

We believe the articles can be grouped into three areas, each article with its own unique contributions. The first two articles draw attention to the political dimensions of pastoral care and how this might alter pastoral theology methodology, addressing its possibilities as a form of public theology. In his article, Ryan LaMothe contends that pastoral theology can contribute to the political theological discourse. Toward this end he offers a general outline for a political pastoral theology. Troels Nørager argues that pastoral care and politics is a sub-set of the larger issue of religion and politics in a democratic society. He focuses on two interrelated issues: the compatibility of religion and democracy, and the connection between religion and morality.

The second grouping of articles addresses some aspects of how pastoral care and pastoral theology respond to diversity and oppression. Richard Coble's essay examines Anton Boisen's political negotiations within the identity categories of ministry and madness in the aftermath of his own repeated episodes of psychosis. He argues that while Boisen sought to change many of the practices of pastoral care for those consigned to madness, he simultaneously reestablished the very boundaries and exclusions he sought to displace. The next article, by Hellena Moon, discusses the oppressive political effects of Asian theologies that idealize sorrow and personal sacrifice. The article by Cody Sander questions whether traditional or theistic theologies intrinsically lend themselves to violence and oppression, proposing a way for pastoral theology to move beyond metaphysical and foundationalist thought. Nancy Ramsay suggests the adoption of an intersectional theoretical approach that furthers the efforts of pastoral theologians as they seek to analyze, engage, and resist oppression and privilege in response to forms of difference.

R. LaMothe $(\bowtie)$

Pastoral Care and Counseling, St. Meinrad Seminary and School of Theology, St. Meinrad, IN, USA

e-mail: rlamothe@saintmeinrad.edu 
The third block of articles focuses on diverse loci in which political aspects may or may not contribute to care. Larry Graham examines some central political aspects of the pastoral caregiver's repertoire that might further enhance a community's ritual and rhetorical resources necessary to sustain life, share loss, reclaim goodness, and rebuild for a strong future. Joretta Marshall explores the political character of public and interpersonal acts of apology and forgiveness. She notes that "power reminds us how apologies function as part of larger political agendas, sometimes bringing greater justice while, at other times, obfuscating ways forward." And finally, Bruce Rogers-Vaughn investigates the political character of what is usually considered a private affect (depression), noting both the politicaleconomic forces that give shape to depression and depression as a form of resistance.

Bruce and I want to recognize Lewis Rambo's yeoman service as Editor of Pastoral Psychology and express our deep appreciation for his support and interest in this project Finally, we hope readers find much food for thought in these articles and consider ways to keep the conversation going. You never know... 